\title{
Strength of forest-albedo feedback in mid-Holocene climate simulations
}

\author{
J. Otto ${ }^{1,2, *}$, T. Raddatz ${ }^{1}$, and M. Claussen ${ }^{1,3}$ \\ ${ }^{1}$ Max Planck Institute for Meteorology, Hamburg, Germany \\ ${ }^{2}$ International Max Planck Research School on Earth System Modelling, Hamburg, Germany \\ ${ }^{3}$ Meteorological Institute, University Hamburg, KlimaCampus, Hamburg, Germany \\ *now at: LSCE, Laboratoire des Sciences du Climat et l'Environnement, UMR8212 - CEA-CNRS-UVSQ, \\ Gif-Sur-Yvette, France
}

Received: 4 February 2011 - Published in Clim. Past Discuss.: 1 March 2011

Revised: 1 August 2011 - Accepted: 6 September 2011 - Published: 28 September 2011

\begin{abstract}
Reconstructions of the mid-Holocene climate, 6000 years before present, suggest that spring temperatures were higher at high northern latitudes compared to the preindustrial period. A positive feedback between expansion of forest and climate presumably contributed to this warming. In the presence of snow, forests have a lower albedo than grass land. Therefore, the expansion of forest likely favoured a warming in spring, counteracting the lower insolation at the mid-Holocene.

We investigate the sensitivity of the vegetation-atmosphere interaction under mid-Holocene orbital forcing with respect to the strength of the forest-albedo feedback by using a comprehensive coupled atmosphere-vegetation model (ECHAM5/JSBACH). We perform two sets of model simulations: a first set of simulations with a relatively weak reduction of albedo of snow by forest; and a second set of simulations with a relatively strong reduction of the albedo of snow by forest.

We show that the parameterisation of the albedo of snow leads to uncertainties in the temperature signal. Compared to the set with weak snow masking, the simulations with strong snow masking reveal a spring warming that is three times higher, by $0.34^{\circ} \mathrm{C}$ north of $60^{\circ} \mathrm{N}$. This warming is related to a forest expansion of only $13 \%$.
\end{abstract}

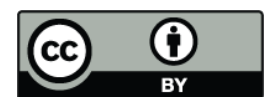

Correspondence to: J. Otto

(juliane.otto@1sce.ipsl.fr)

\section{Introduction}

Most temperature reconstructions indicate that during the mid-Holocene (about 6000 years before present), temperatures were on average higher compared to the pre-industrial period at high northern latitudes. On average, the climate north of $60^{\circ} \mathrm{N}$ was $\sim 1.0^{\circ} \mathrm{C}$ warmer in summer, $\sim 1.7^{\circ} \mathrm{C}$ warmer in winter, and $\sim 2.0^{\circ} \mathrm{C}$ warmer in the annual mean in comparison to the pre-industrial climate (Sundqvist et al., 2010a,b). It is striking that the reconstructed annual mean temperature is higher than the winter and summer temperature. Sundqvist et al. (2010a) propose that the mid-Holocene spring and autumn temperatures may have been considerably higher than in the reconstructed winter and summer temperatures.

Higher temperatures during autumn were likely caused by the stronger mid-Holocene insolation at early autumn (Berger, 1978). Higher temperatures during spring, however, cannot be explained by the insolation signal, as the high northern latitudes received less insolation during midHolocene spring compared to the pre-industrial period. This leads to the assumption that some feedbacks between the land surface and atmosphere may have caused warmer springs during the mid-Holocene.

In fact, there exists a strong feedback between snowcovered land and the climate, as snow covered forest has a lower albedo than snow-covered lower vegetation. Trees protrude the snow layer and hence decrease the high albedo of snow (Otterman et al., 1984). Additionally, vegetation reconstructions for the mid-Holocene show that boreal forest cover increased and expanded to the north. In Northwestern

Published by Copernicus Publications on behalf of the European Geosciences Union. 
Canada and Northern Eurasia, the treeline advanced near to the Arctic coastline and reached its northern most position of the Holocene period (MacDonald et al., 2000). Presumably, the warmer conditions during mid-Holocene summer favoured the growth of forest, which led to a decrease in albedo during the cold season and favoured higher temperatures in spring which reinforced the growth of forest (Claussen, 2004).

Studies with climate models corroborate the assumption of higher mid-Holocene spring temperatures by this positive vegetation-climate feedback. To determine the impact of this feedback to the spring temperature, modelling studies followed a specific experiment setup that allowed them to separate the different contributions to the climate signal (Stein and Alpert, 1993). These contributions can be defined as pure contribution of the vegetation-atmosphere interaction (without interaction between climate and ocean), as pure contribution of the ocean-atmosphere interaction (without interaction between climate and vegetation patterns), and as synergy that emerges due to the interaction between vegetationatmosphere and ocean-atmosphere interaction. Ganopolski et al. (1998) initiated this approach for the mid-Holocene and found a weak pure contribution due to vegetation-atmosphere interaction, but a strong synergy. Crucifix et al. (2002) obtained a strong vegetation-atmosphere interaction, but a weaker synergy compared to Ganopolski et al. (1998). A following study by Wohlfahrt et al. (2004) showed as well a weak synergy but a stronger contribution by the vegetationatmosphere interaction than Ganopolski et al. (1998). A most recent study indicated that mainly the pure ocean-atmosphere interaction dominated the mid-Holocene temperatures (Otto et al., 2009b).

The discrepancy between the different model results may be related to the usage of different models and parameterisations. Previous work has revealed that the albedo values of snow-covered surfaces vary strongly among the suite of general circulation models (GCMs) used in the Fourth Assessment Report of the Intergovernmental Panel on Climate Change (Meehl et al., 2007). The range of albedo values in the models is shown to have a direct impact on the spread in projections of climate change over the continental interior of North America (Hall et al., 2008). Thus, we assume that the spread of albedo values may also lead to a spread of temperature signals in simulations of mid-Holocene climate. To test this assumption, we investigate how much the parameterisation of the albedo of snow-covered forest influences the pure contribution of vegetation-atmosphere interaction to the midHolocene spring warming. For this purpose, we analyse two different sets of simulations: (a) simulations with a relatively weak reduction of albedo of snow by forest, and (b) simulations with a relatively strong reduction of the albedo of snow by forest.

\section{The albedo scheme in JSBACH}

We performed this study with the Earth system model of the Max Planck Institute for Meteorology (MPI-ESM), which includes the atmospheric model ECHAM5 (Roeckner et al., 2003) and the land surface Jena Scheme for Biosphere-Atmosphere Coupling in Hamburg (JSBACH) (Raddatz et al., 2007) including a dynamic vegetation module (Brovkin et al., 2009). The model was run with 19 vertical levels in resolution of T31, which corresponds to approximately $3.75^{\circ}$.

The albedo scheme in JSBACH computes the temporal and spatial changes of the land-surface albedo (see Appendix A). It provides a spatially explicit surface albedo calculation for the near infrared (NIR) as well as for the visible range (VIS).

In general, the albedo is calculated separately for surfaces covered by green leaves and covered by soil. If the land surface is snow covered, the albedo of a snow-covered fraction of the grid box and the albedo of snow-covered forest canopies is additionally computed. A detailed description of the albedo calculation in JSBACH is given in Appendix B.

We performed two sets of simulations. The first set of simulations was performed with a weak reduction of the albedo of snow by forest. We call this reduction of the albedo of snow "the strength of snow masking" $\left(\delta_{\alpha}\right)$, defined as the difference between the albedo of grass and forest which is higher than 0.1 only in the presence of snow. The strength of snow masking depends on the type of forest (deciduous or evergreen forest). In the set of simulations with a weak strength of snow masking, particularly deciduous forest has a small effect on the albedo of snow because of the loss of its foliage during the cold season.

The second set of simulations is performed with an enhanced snow masking by forest, in particular by deciduous forest. In general, the calculation of the albedo depends on the leaf area index (LAI), which determines how much of the fraction is shaded by the canopy (see Appendix B). As during winter LAI of deciduous forest is very low, Roesch and Roeckner (2006) suggested to introduce a stem area index to replace LAI for deciduous trees in winter. When deciduous trees have lost their needles or leaves, this stem area index mimics the stem and branches shadowing the ground below the canopy. The current parameterisation includes a stem area index set to 1 which introduces a weak snow masking for deciduous forest (Fig. 1). To account for a stronger snow masking by deciduous forest, we set the stem area index to 3 . In addition, we introduced a stronger snow masking by evergreen forest by reducing the albedo of snow-covered canopy from $\alpha_{\text {snow,c }}=0.25$ to $\alpha_{\text {snow,c }}=0.20$ (Sturm et al., 2005), and we increased the minimum albedo of snow for bare lands in the near infrared from $\alpha_{\text {snow, nir }}=0.3$ to $\alpha_{\text {snow,nir }}=0.4$. 

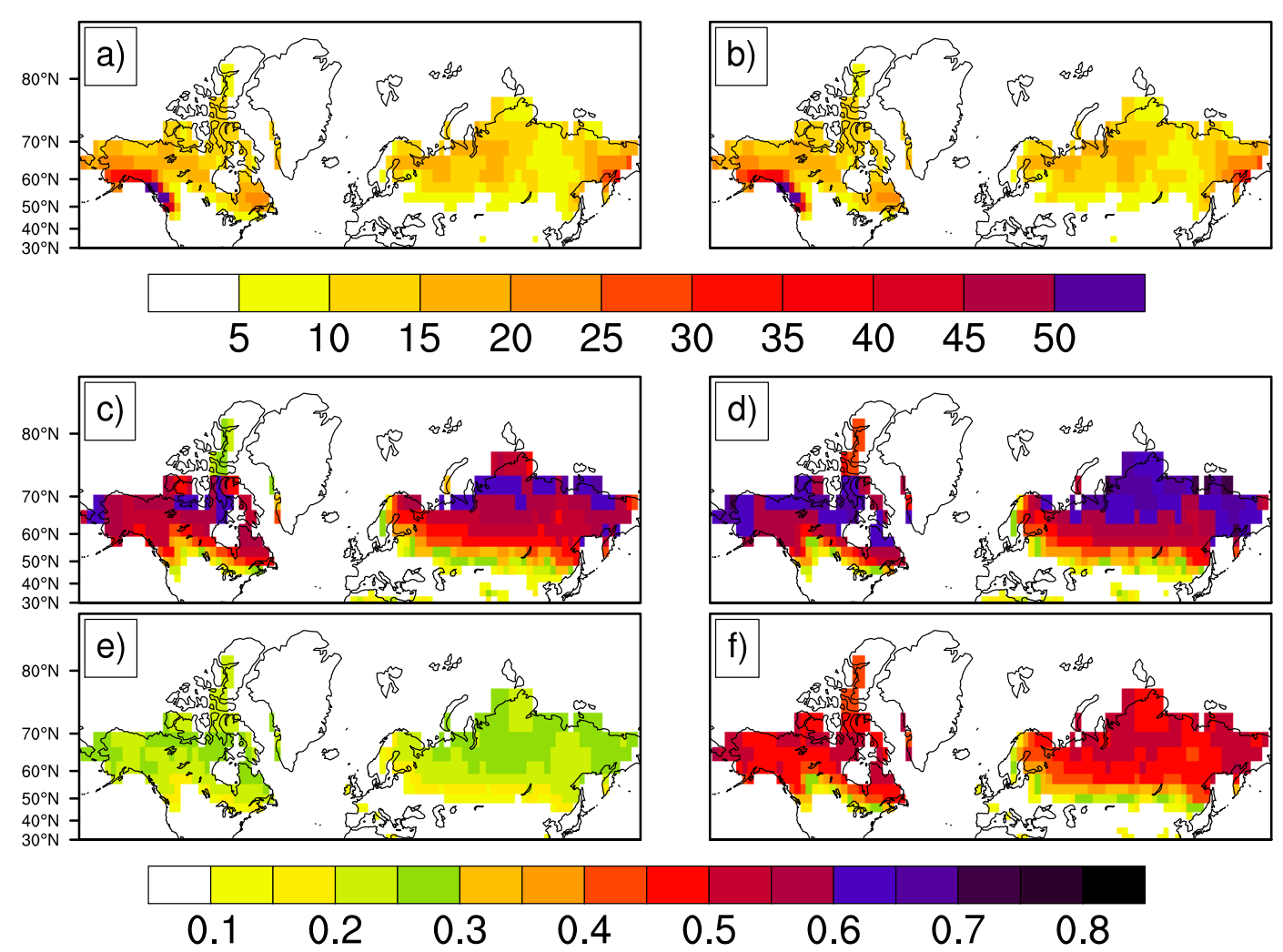

Fig. 1. This figure shows the snow-masking performance of MPI-ESM based on the pre-industrial simulations $0 \mathrm{k}(\mathrm{AV})_{\mathrm{w}}$ and $0 \mathrm{k}(\mathrm{AV})_{\mathrm{S}}$ with weak and strong snow masking, respectively. The upper two panels show the snow water equivalent in $\mathrm{cm}$ for March for both parameterisations with weak snow masking (a) and with strong snow masking (b). The panels below show the difference between the albedo of grass $\left(\right.$ VIS + NIR) and the albedo of forest (VIS + NIR) for March. We refer to this difference as strength of snow-masking $\left(\delta_{\alpha}\right)$. The left column shows $\delta_{\alpha}$ for the parameterisation with weak snow masking separately for evergreen forest (c) and for deciduous forest (e). The right column shows $\delta_{\alpha}$ for the parameterisation with strong snow masking separately for evergreen forest (d) and for deciduous forest (f).

\section{The simulation protocol}

In a previous study (Otto et al., 2009a,b) we used the factor separation method by Stein and Alpert (1993) to explore the relative contributions of the vegetation-atmosphere feedback, the atmosphere-ocean feedback, and the synergy effect between them to the difference in temperature patterns north of $40^{\circ} \mathrm{N}$ between mid-Holocene and pre-industrial climate. Here we focus on a detailed investigation of the pure contribution by the vegetation-atmosphere interaction only. Hence, we have excluded any synergistic effects by the ocean dynamics.

The term "vegetation-climate interaction" comprises all interactions between vegetation and atmosphere and determines the pure contribution of this interaction to the midHolocene climate signal. To calculate this pure vegetationatmosphere contribution, a set of four simulations is necessary: two simulations including dynamic atmosphere and vegetation (referred to as $\mathrm{AV}$ ) for $0 \mathrm{k}$ and $6 \mathrm{k}$, respectively, and two simulations with prescribed vegetation (referred to as $A$ ) for $0 \mathrm{k}$ and $6 \mathrm{k}$, respectively. It is sufficient to perform the four simulations with the same prescribed ocean (Berger et al., 2011). Thus, all simulations are performed with the same prescribed monthly mean of SST (sea surface temperature) and sea-ice cover from a pre-industrial 0k AOV control run. On the basis of these four simulations we determine the pure contribution of the vegetation-atmosphere interaction to the mid-Holocene climate signal.

Here we aim to test the sensitivity of this pure vegetationatmosphere contribution towards the parameterisation of the albedo of snow. Thus, two sets of simulations (each including four simulations) were conducted: four simulations with weak snow masking $\left(6 \mathrm{k}(\mathrm{AV})_{\mathrm{w}}, 0 \mathrm{k}(\mathrm{AV})_{\mathrm{w}}, 6 \mathrm{k} A_{\mathrm{w}}, 0 \mathrm{k} A_{\mathrm{w}}\right)$ to calculate the pure contribution of the vegetation-atmosphere interaction $\Delta V_{\mathrm{w}}$; and four simulations with strong snow masking $\left(6 \mathrm{k}(\mathrm{AV})_{\mathrm{s}}, 0 \mathrm{k}(\mathrm{AV})_{\mathrm{s}}, 6 \mathrm{k} A_{\mathrm{s}}, 0 \mathrm{k} A_{\mathrm{s}}\right)$ to calculate the pure contribution of the vegetation-atmosphere interaction $\Delta V_{\mathrm{s}}$ to the mid-Holocene climate signal (see Table 1). First, two simulations with dynamic vegetation and pre-industrial orbital forcing $0 \mathrm{k}(\mathrm{AV})_{\mathrm{w}}$ and $0 \mathrm{k}(\mathrm{AV})_{\mathrm{s}}$, and two simulations with mid-Holocene orbital forcing $6 \mathrm{k}(\mathrm{AV})_{\mathrm{w}}$ and $6 \mathrm{k}(\mathrm{AV})_{\mathrm{s}}$ were performed. Next, two atmosphere-only simulations with fixed vegetation and pre-industrial orbital forcing $0 \mathrm{k} A_{\mathrm{w}}$ and $0 \mathrm{k} A_{\mathrm{s}}$, and two atmosphere-only simulations with fixed 
Table 1. List of experiment setup and simulations.

\begin{tabular}{|c|c|c|c|}
\hline $\begin{array}{l}\text { experiment } \\
\text { name }\end{array}$ & $\begin{array}{c}\text { prescribed } \\
\text { vegetation cover }\end{array}$ & $\begin{array}{l}\text { prescribed SST } \\
\text { and sea-ice cover }\end{array}$ & $\begin{array}{c}\text { duration } \\
\text { (yrs) }\end{array}$ \\
\hline \multicolumn{4}{|c|}{ weak snow masking } \\
\hline \multicolumn{4}{|l|}{$\Delta V_{\mathrm{W}}$} \\
\hline $6 \mathrm{k}(\mathrm{AV})_{\mathrm{W}}$ & - & $0 \mathrm{k}(\mathrm{AOV})_{\mathrm{W}}$ & 480 \\
\hline $0 \mathrm{k}(\mathrm{AV})_{\mathrm{W}}$ & - & $0 \mathrm{k}(\mathrm{AOV})_{\mathrm{W}}$ & 480 \\
\hline $6 \mathrm{k} A_{\mathrm{W}}$ & from $0 \mathrm{k}(\mathrm{AV})_{\mathrm{W}}$ & $0 \mathrm{k}(\mathrm{AOV})_{\mathrm{W}}$ & 250 \\
\hline $0 \mathrm{k} A_{\mathrm{W}}$ & from $0 \mathrm{k}(\mathrm{AV})_{\mathrm{W}}$ & $0 \mathrm{k}(\mathrm{AOV})_{\mathrm{w}}$ & 250 \\
\hline \multicolumn{4}{|c|}{ strong snow masking } \\
\hline$\Delta V_{\mathrm{S}}$ & & & \\
\hline $6 \mathrm{k}(\mathrm{AV})_{\mathrm{s}}$ & - & $0 \mathrm{k}(\mathrm{AOV})_{\mathrm{W}}$ & 480 \\
\hline $0 \mathrm{k}(\mathrm{AV})_{\mathrm{s}}$ & - & $0 \mathrm{k}(\mathrm{AOV})_{\mathrm{W}}$ & 480 \\
\hline $6 \mathrm{k} A_{\mathrm{s}}$ & from $0 \mathrm{k}(\mathrm{AV})_{\mathrm{s}}$ & $0 \mathrm{k}(\mathrm{AOV})_{\mathrm{W}}$ & 250 \\
\hline $0 \mathrm{k} A_{\mathrm{s}}$ & from $0 \mathrm{k}(\mathrm{AV})_{\mathrm{s}}$ & $0 \mathrm{k}(\mathrm{AOV})_{\mathrm{W}}$ & 250 \\
\hline
\end{tabular}

vegetation and mid-Holocene orbital forcing $6 \mathrm{k} A_{\mathrm{w}}$ and $6 \mathrm{k} A_{\mathrm{s}}$ were performed. Each of these atmosphere-only simulations had prescribed the mean distribution of the plant functional types (PFTs) from the $0 \mathrm{k}(\mathrm{AV})_{\mathrm{w}}$-simulation and the $0 \mathrm{k}(\mathrm{AV})_{\mathrm{s}}$ simulation, respectively. To calculate the pure contribution of the vegetation-climate interaction $\Delta V_{\mathrm{w}}$ and $\Delta V_{\mathrm{s}}$, we have to compare the results of the two simulations with the vegetation run interactively with the two atmosphere-only simulations:

$$
\begin{aligned}
& \Delta V_{\mathrm{w}}=\left(6 \mathrm{k}(\mathrm{AV})_{\mathrm{w}}-0 \mathrm{k}(\mathrm{AV})_{\mathrm{w}}\right)-\left(6 \mathrm{k} A_{\mathrm{w}}-0 \mathrm{k} A_{\mathrm{w}}\right) \\
& \Delta V_{\mathrm{s}}=\left(6 \mathrm{k}(\mathrm{AV})_{\mathrm{s}}-0 \mathrm{k}(\mathrm{AV})_{\mathrm{s}}\right)-\left(6 \mathrm{k} A_{\mathrm{s}}-0 \mathrm{k} A_{\mathrm{s}}\right)
\end{aligned}
$$

The pure contribution $\Delta V_{\mathrm{w}}$ and $\Delta V_{\mathrm{s}}$ can be evaluated for all climate parameters. If we consider a specific climate parameter, for example the air temperature [T], we use the symbol $\Delta V_{\mathrm{w}}[T]$ and $\Delta V_{\mathrm{s}}[T]$, respectively.

To ensure statistically robust results (Otto et al., 2009a), we simulated 250 years for the atmosphere-only runs and 480 years for the vegetation-atmosphere runs and considered the last 240 years of all experiments for the analysis. All results presented cover an average over 240 years. All simulations were run with atmospheric $\mathrm{CO}_{2}$-concentrations set to $280 \mathrm{ppm}$.

\section{Snow-masking parameterisations}

A strong reduction in surface albedo by forest emerges solely with the presence of snow. This effect is mostly confined to the land north of $50^{\circ} \mathrm{N}$ as seen in Fig. 1a and b. The figures show the simulated snow water equivalent just before the melting season in the Northern Hemisphere for $0 \mathrm{k}(\mathrm{AV})_{\mathrm{w}}$ and $0 \mathrm{k}(\mathrm{AV})_{\mathrm{s}}$. Considering the parameterisation with weak snow masking, the albedo of snow covered land is much more effectively reduced by evergreen forest than by deciduous forest (Fig. 1c and e). Albedo of grassland is up to 0.65 lower than the albedo of evergreen forest, whereas this albedo reduction is limited to 0.30 . In the simulations performed with strong snow masking, the maximum strength of snow masking by evergreen forest is increased by 0.05 and covers a larger area than with the weak snow masking simulations. The strength of snow masking by deciduous forest is increased by almost a factor of two due to the larger stem area index. The strength ranges from 0.1 to 0.5 and is strongest in the region between $55-70^{\circ} \mathrm{N}$.

The albedo of snow can be measured by aircraft and satellite, remote sensing, and ground observations (e.g. Essery et al., 2009; Barlage et al., 2005; Jin et al., 2002; Betts and Ball, 1997). These measurements show that the albedo of snow is strongly variable and depends on various factors like, for example, the type of snow, weather conditions, and size of sample area (Moody et al., 2007). Hence, the estimates for the strength of the snow masking vary in the literature (Table 2) between 0.1 and 0.6 for evergreen forest and 0.1 and 0.5 for deciduous forest. All studies agree in that evergreen forest masks the albedo of snow more effectively than deciduous forest. This feature is captured by JSBACH. In both parameterisations, the simulated strength of snow masking by both deciduous and evergreen forest is in general agreement with snow masking that was observed. The simulated strong snow masking by evergreen forest exceeds the upper end of the range of snow masking that was observed by 0.1 .

\section{Simulated vegetation-climate interaction}

Spring is the season when the high northern latitudes are still partly covered by snow and receive a large amount of incoming solar radiation as opposed to winter. This is the reason why the forest-albedo feedback is expected to be most pronounced in this season (Hall and Qu, 2006; Dery and Brown, 2007).

In this study, spring is defined by astronomical dates from vernal equinox to summer solstice. This is necessary in order to keep the definition of seasons consistent with insolation forcing in pre-industrial and mid-Holocene climates (Joussaume and Braconnot, 1997). Since an astronomical calendar is not implemented in our model, we calculated spring from the daily output according to the model's astronomical parameters for pre-industrial and for mid-Holocene climate, respectively (Timm et al., 2008). In previous mid-Holocene studies, spring was determined by monthly means (March, April, May) that were computed with the present-day calendar. To compare our results with previous studies, we shifted the season backwards by three weeks ( 21 days), according to the astronomical season. For example, at 0k the vernal equinox is reached on $22 \mathrm{March}$, i.e. the 0k spring starts on 1 March and lasts until 31 May in our analysis. At 6k spring 
Table 2. Strength of snow masking of MPI-ESM and values from literature.

\begin{tabular}{|c|c|c|c|c|c|}
\hline & $\begin{array}{l}\text { weak snow } \\
\text { masking }\end{array}$ & $\begin{array}{l}\text { strong snow } \\
\text { masking }\end{array}$ & measurements & $\begin{array}{l}\text { type of } \\
\text { measurements }\end{array}$ & reference \\
\hline $\begin{array}{l}\text { albedo of grass } \\
\text { - albedo of } \\
\text { evergreen forest }\end{array}$ & $0.1-0.6$ & $0.1-0.7$ & $\begin{array}{l}0.5-0.6 \\
0.3 \\
0.1-0.5 \\
0.2 \\
0.6\end{array}$ & $\begin{array}{l}\text { three sites } \\
\text { satellite } \\
\text { satellite } \\
\text { satellite } \\
\text { ten sites }\end{array}$ & $\begin{array}{l}\text { Essery et al. (2009) } \\
\text { Moody et al. (2007) } \\
\text { Barlage et al. (2005) } \\
\text { Jin et al. (2002) } \\
\text { Betts and Ball (1997) }\end{array}$ \\
\hline $\begin{array}{l}\text { albedo of grass } \\
\text { - albedo of } \\
\text { deciduous forest }\end{array}$ & $0.1-0.3$ & $0.1-0.5$ & $\begin{array}{l}- \\
0.3 \\
0.1-0.5 \\
0.1-0.3 \\
0.5\end{array}$ & $\begin{array}{l}\text { three sites } \\
\text { satellite } \\
\text { satellite } \\
\text { satellite } \\
\text { ten sites }\end{array}$ & $\begin{array}{l}\text { Essery et al. (2009) } \\
\text { Moody et al. (2007) } \\
\text { Barlage et al. (2005) } \\
\text { Jin et al. (2002) } \\
\text { Betts and Ball (1997) }\end{array}$ \\
\hline
\end{tabular}

starts three days later and ends four days later compared to $0 \mathrm{k}$ spring. Spring average is then computed from the daily output of the model for the pre-industrial and the mid-Holocene period, respectively.

The experiments with weak snow masking yield a spring warming of $\Delta V_{\mathrm{w}}[T]=0.12^{\circ} \mathrm{C}$ (Table 3) for the land north of $60^{\circ} \mathrm{N}$. The positive temperature anomaly is largest in the circum-polar belt between $60-70^{\circ} \mathrm{C}$ (Fig. 2a). The temperature increases locally up to $0.60^{\circ} \mathrm{C}$. The simulations with strong snow masking result in higher spring temperatures. The warming is most pronounced in Eastern Siberia. Here the forest expansion increases the temperature by up to $1.3^{\circ} \mathrm{C}\left(\Delta V_{\mathrm{s}}[T]\right)$ (Fig. 2b). Averaged over the land region north of $60^{\circ} \mathrm{N}$, the temperature increase is $\Delta V_{\mathrm{s}}[T]=0.34^{\circ} \mathrm{C}$, and hence is almost three times higher than with the weak snow masking.

The basis for a strong vegetation-climate interaction during the mid-Holocene is the expansion of forest. As reconstructions indicate, the tree line was shifted further north to the Arctic coast line (MacDonald et al., 2000). Both simulation sets produce this forest expansion for the region north of $60^{\circ} \mathrm{N}$ (Fig. 3). The simulations with weak snow masking result in a forest increase by $11.29 \times 10^{5} \mathrm{~km}^{2}$, the simulations with strong snow masking yield a $13 \%$ stronger increase by $12.71 \times 10^{5} \mathrm{~km}^{2}$. The forest expansion comprises both the increase in evergreen and deciduous forest but in varying degree. Evergreen forest increases in Northern Europe, North-Western Siberia, and Northern Canada. The simulations with strong snow masking result in a $2 \times 10^{5} \mathrm{~km}^{2}$ larger expansion of evergreen forest and $0.56 \times 10^{5} \mathrm{~km}^{2}$ smaller expansion of deciduous forest relative to the simulations with weak snow masking.

The set of simulations with strong snow masking reduces the surface albedo more strongly than with weak snow masking (Fig. $2 \mathrm{c}$ and d). In the belt between $60-70^{\circ} \mathrm{N}$, the surface albedo is almost everywhere reduced up to $\Delta V_{\mathrm{s}}[\alpha]=-0.14$ compared to $\Delta V_{\mathrm{w}}[\alpha]=-0.08$ in the experiment with weak
Table 3. Change in vegetation and desert fraction of the atmosphere-vegetation simulations $(\mathrm{AV})_{\mathrm{W}}$ and $(\mathrm{AV})_{\mathrm{s}}$. Below the climate parameters of the pure atmosphere-vegetation interaction of the simulations with both weak snow masking, $\Delta V_{\mathrm{W}}$, and strong snow masking, $\Delta V_{\mathrm{s}}$. The change in vegetation cover is derived from the simulations with dynamic vegetation. All values are spring mean values and averaged over land over the area $60^{\circ}-90^{\circ} \mathrm{N}$. Please note that fluxes towards the atmosphere (sensible and latent heat fluxes) are negative.

\begin{tabular}{lcc}
\hline Change in vegetation and desert in $10^{5} \mathrm{~km}^{2}$ & $(\mathrm{AV})_{\mathrm{W}}$ & $(\mathrm{AV})_{\mathrm{s}}$ \\
\hline Evergreen forest & 4.84 & 6.82 \\
Deciduous forest & 6.45 & 5.89 \\
Grass & -1.68 & -1.96 \\
Shrubs & -0.46 & 0.03 \\
Desert fraction & -9.15 & -10.78 \\
\hline Climate change in spring & $\Delta V_{\mathrm{W}}$ & $\Delta V_{\mathrm{s}}$ \\
\hline Air-temperature $\left[{ }^{\circ} \mathrm{C}\right]$ & $0.12^{*}$ & $0.34^{* *}$ \\
Surface albedo $[-]$ & $-0.02^{* *}$ & $-0.03^{* *}$ \\
Precipitation [mm season $\left.{ }^{-1}\right]$ & 0.28 & 0.85 \\
Snow water equivalent [mm] & -0.53 & $-1.70^{* *}$ \\
Sensible heat flux in $\left[\mathrm{W} \mathrm{m}^{-2}\right]$ & $-0.42^{* *}$ & $-0.72^{* *}$ \\
Latent heat flux in [W m $\left.{ }^{-2}\right]$ & $-0.38^{* *}$ & $-0.69^{* *}$ \\
Net surface solar radiation [W m $\left.{ }^{-2}\right]$ & $1.05^{* *}$ & $1.77^{* *}$ \\
Cloud cover fraction $[-]$ & 0.002 & $0.004^{* *}$ \\
\hline
\end{tabular}

Note: ${ }^{*}$ significant values with a 0.10 level of significance, ${ }^{* *}$ significant values with a 0.05 level of significance.

snow masking. In this latitudinal belt, the net surface solar radiation is increased compared to the pre-industrial period in both experiments (Fig. 2e and f). In North-Eastern Siberia occurs the maximum raise of net surface solar radiation with $12 \mathrm{~W} \mathrm{~m}^{-2}$ in the set of simulations with strong snow masking $\left(\Delta V_{\mathrm{s}}[S]\right)$. This is more than twice the radiation that is available at surface in the set of simulations with weak snow masking. In both experiments the patterns 

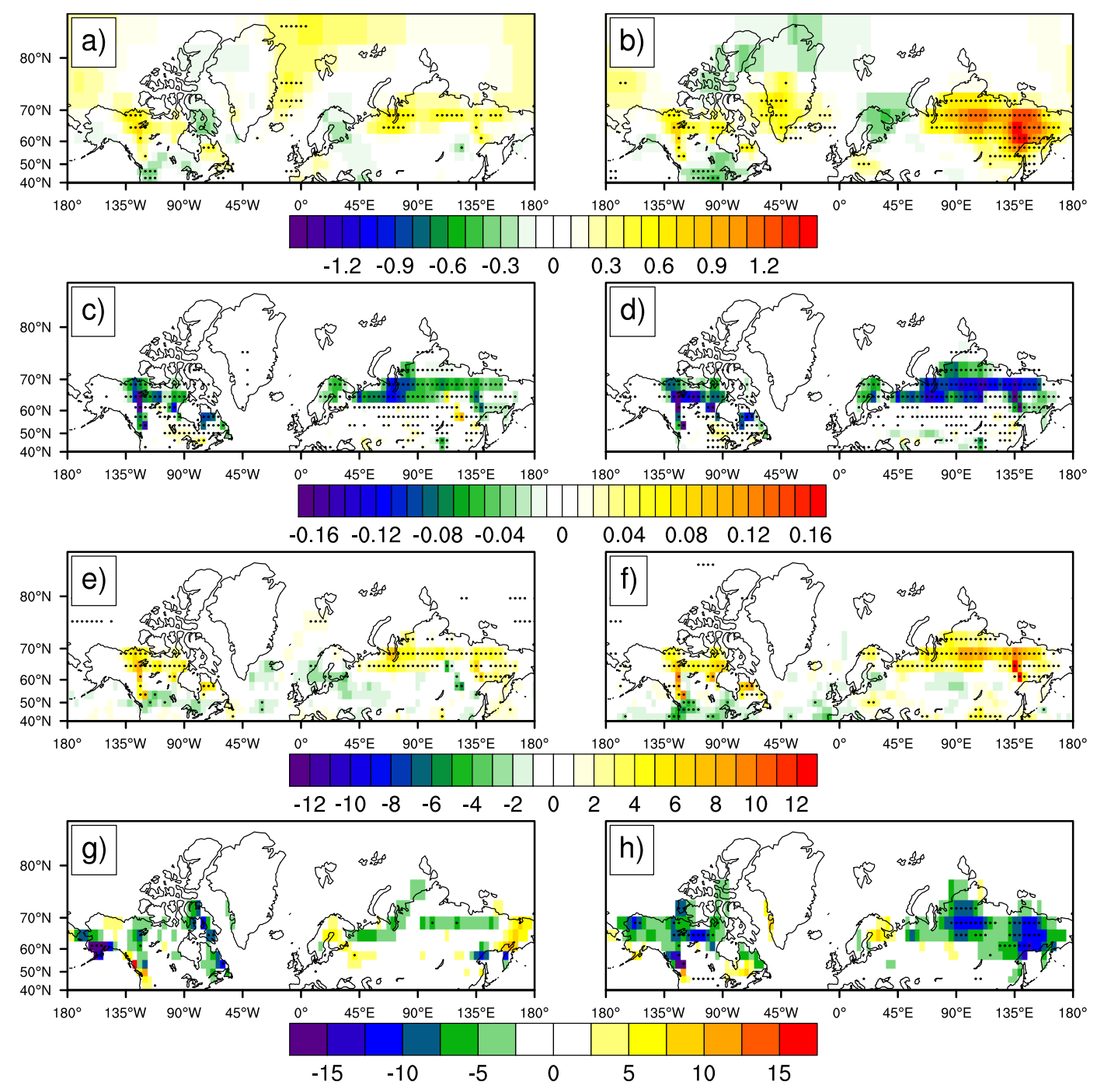

Fig. 2. Mean spring climate values for $\Delta V_{\mathrm{W}}$ (left column) and $\Delta V_{\mathrm{S}}$ (right column): air-temperature in ${ }^{\circ} \mathrm{C}$ (a) and (b), surface albedo (c) and (d), net surface solar radiation in $\mathrm{W} \mathrm{m}^{-2}$ (e) and (f), snow water equivalent in $\mathrm{mm}$ (g) and (h). The black dots indicate significant values with 0.05 level of significance.

of albedo reduction and the increase in net surface solar radiation follow roughly the patterns of forest increase (Fig. 3).

It is striking that only the simulations with strong snow masking show a lower snow water equivalent in spring compared to the pre-industrial period (Fig. $2 \mathrm{~g}$ and $\mathrm{h}$ ). Snow is reduced in a slightly larger region than in the region where forest increase (Fig. $3 \mathrm{c}-\mathrm{f}$ ). The snow water equivalent decreases regionally up to $15 \mathrm{~mm}\left(\Delta V_{\mathrm{s}}[\mathrm{SWE}]\right)$, in particular in the regions with strongest expansion in deciduous forest. In the experiment with weak snow masking, the reduction in snow water equivalent does not exceed $5 \mathrm{~mm}\left(\Delta V_{\mathrm{w}}[\mathrm{SWE}]\right)$ and occurs only in the region of strongest forest increase.

To investigate the forest-albedo feedback more closely, we analyse the mean spring cycle (Fig. 4). Figure 4a reveals that in both experiments the temperature anomaly is not constant in spring. With the increase of insolation after winter, temperature rises until it reaches its maximum $\left(\Delta V_{\mathrm{w}}[T]=0.38, \Delta V_{\mathrm{s}}[T]=0.64\right)$. However, maximum temperatures are not reached at the same time in both sets of simulations. The experiment with weak snow masking $\left(\Delta V_{\mathrm{w}}\right)$ shows lower air-temperatures at the beginning of spring and reaches the temperature maximum about one month later than $\Delta V_{\mathrm{s}}$.

Surface albedo is in both experiments considerably lower throughout spring $\left.\Delta V_{\mathrm{w}}[\alpha]=\sim-2 \%, \Delta V_{\mathrm{s}}[\alpha]=\sim-3.6 \%\right)$ relative to the pre-industrial period. However, only the low albedo (Fig. 4c) in the experiment with strong snow masking leads to a considerable increase in surface solar radiation $\left(\Delta V_{\mathrm{s}}[S]=2.6 \mathrm{~W} \mathrm{~m}^{-2}\right)$ (Fig. $\left.4 \mathrm{~b}\right)$. This favours the warming of near-to surface air in spring, leading to melting of snow (Fig. 4d). The surface albedo in the experiment with weak snow masking is not as low as in the simulations with strong 

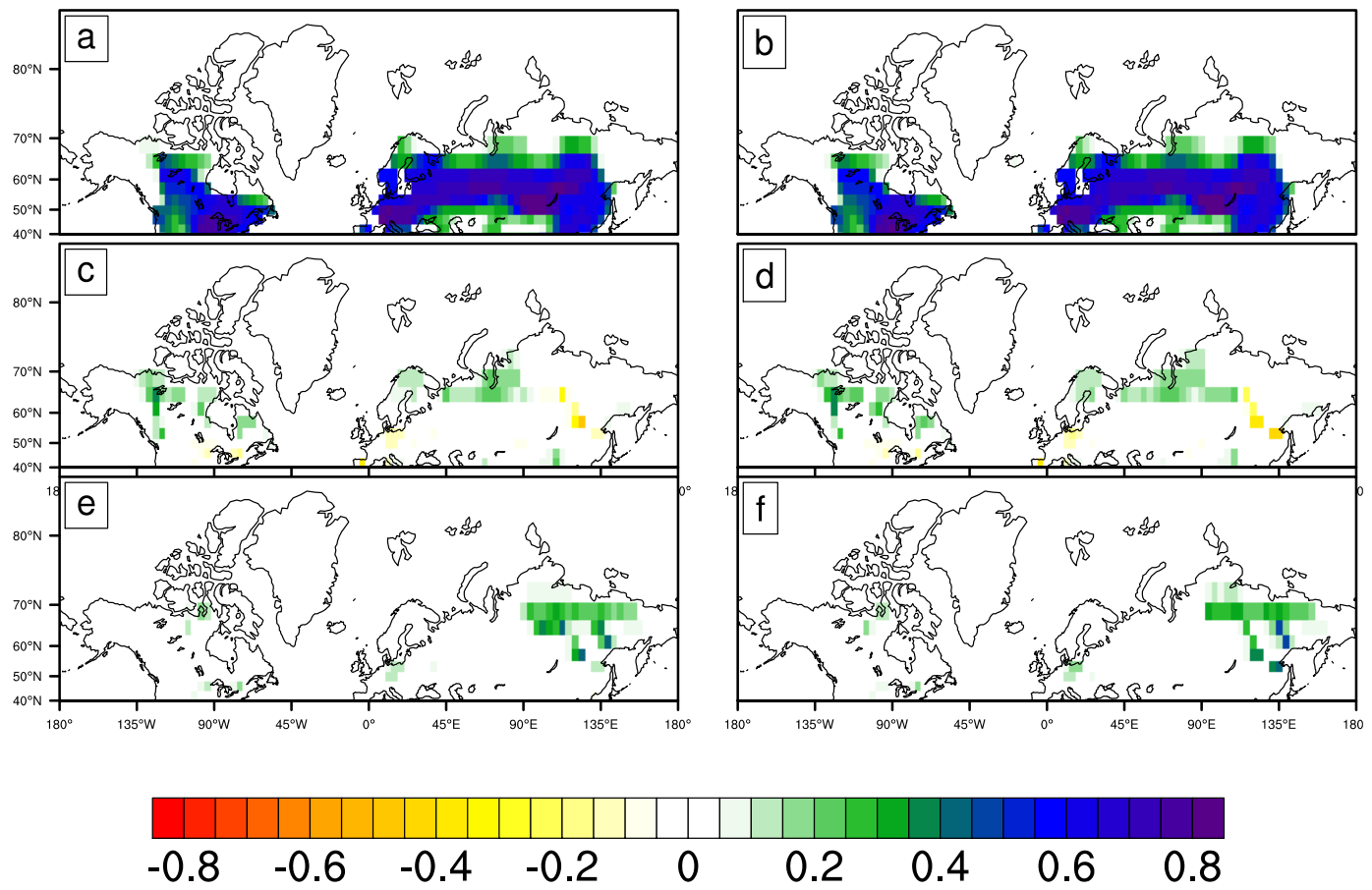

Fig. 3. Forest cover for the two sets of simulations with weak snow masking (left column) and strong snow masking (right column). The upper two panels (a) and (b) give the total forest cover for present day climate $-(\mathbf{a})=0 \mathrm{k}(\mathrm{AV})_{\mathrm{W}}$ and $(\mathbf{b})=0 \mathrm{k}(\mathrm{AV})_{\mathrm{S}}$. The panels $(\mathbf{c})$ and (d) show the change in evergreen forest $-(\mathbf{c})=6 \mathrm{k}(\mathrm{AV})_{\mathrm{W}}-0 \mathrm{k}(\mathrm{AV})_{\mathrm{W}},(\mathbf{d})=6 \mathrm{k}(\mathrm{AV})_{\mathrm{S}}-0 \mathrm{k}(\mathrm{AV})_{\mathrm{S}}$; the panels (e) and (f) for deciduous forest $(\mathbf{e})=6 \mathrm{k}(\mathrm{AV})_{\mathrm{W}}-0 \mathrm{k}(\mathrm{AV})_{\mathrm{W}},(\mathbf{f})=6 \mathrm{k}(\mathrm{AV})_{\mathrm{s}}-0 \mathrm{k}(\mathrm{AV})_{\mathrm{s}}$.

snow masking. The consequence is that less radiation is absorbed to warm the air and to effectively melt snow. Hence, the feedback between snow-covered forest and atmosphere is not as strong as in the experiment with strong snow masking, resulting in lower spring temperatures.

As the snow masking by forest is in the simulations with low snow masking too weak to considerably warm spring air, our objective is to test whether the expansion of forest and its snow masking are actually the main land components that drive vegetation-climate interactions. We compare the simulated net surface downward radiation signal $\Delta V_{\mathrm{w}}[S]$ with a simple estimate of the change in net surface solar radiation $\left(\delta S_{\text {est }}\right)$ due to the strength of snow masking and the change in forest. We multiply the solar downward radiation of $0 \mathrm{k} A_{\mathrm{w}}$ by the strength of the snow masking for evergreen and deciduous forest, respectively, (see Fig. $1 \mathrm{c}-\mathrm{f}$ ) and by the change in forest for evergreen and deciduous forest, respectively, between the mid-Holocene and pre-industrial simulations $\left(\Delta(\mathrm{AV})_{\mathrm{W}}\right)$ and average this product for the spring season:

$\delta S_{\mathrm{est}}=\int_{t_{1}}^{t_{2}} S \downarrow\left(\delta \alpha_{\mathrm{e}} \cdot \Delta f_{\mathrm{e}}+\delta \alpha_{\mathrm{d}} \cdot \Delta f_{\mathrm{d}}\right) \mathrm{d} t /\left(t_{2}-t_{1}\right)$

where $S \downarrow$ is the solar downward radiation in $\mathrm{W} \mathrm{m}^{-2}$ for $0 \mathrm{k}$, $\delta \alpha_{\mathrm{e}}$ is the strength of snow masking of evergreen forest, $\delta \alpha_{\mathrm{d}}$ is the strength of snow masking of deciduous forest, $\Delta f_{\mathrm{e}}$ the change in evergreen forest fraction and $\Delta f_{\mathrm{d}}$ the change in deciduous forest fraction between $6 \mathrm{k}$ and $0 \mathrm{k}$, and $t_{1}$ represents the date of the beginning of spring and $t_{2}$ the date of the end of spring.

Figure 5 shows the estimated net surface solar radiation $\delta S_{\text {est }}$ and the simulated net surface solar radiation $\Delta V_{\mathrm{w}}[S]$. The patterns of change in net surface solar radiation are very similar. However, $\delta S_{\text {est }}$ reveals a stronger increase in net surface solar radiation compared to the simulated net surface solar radiation by about a factor of two. In addition, $\delta S_{\text {est }}$ does not produce the reduction in net surface solar radiation of the region over North America between $40-60^{\circ} \mathrm{N}$ and NorthEast Europe. We can support the statement that in our model the expansion of forest and its snow masking are the main land components that drive of the vegetation-climate interaction (Otterman et al., 1984; Harvey, 1988).

The deviation of the estimated net surface solar radiation $\delta S_{\text {est }}$ from the simulated net surface solar radiation $\Delta V_{\mathrm{w}}[S]$ indicates that the net surface solar radiation is weakened by a process which is not included in the simple estimate (Eq. 3). This process could be an increase in cloud fraction due to the fact that trees have a more productive canopy than grass and shrubs, and therefore transpire more water (Pielke and Vidale, 1995; Eugster et al., 2000; Beringer et al., 2005). In addition, trees start to sprout in spring when leaves emerge and enhance transpiration (Schwartz and Karl, 1990; Chapin 

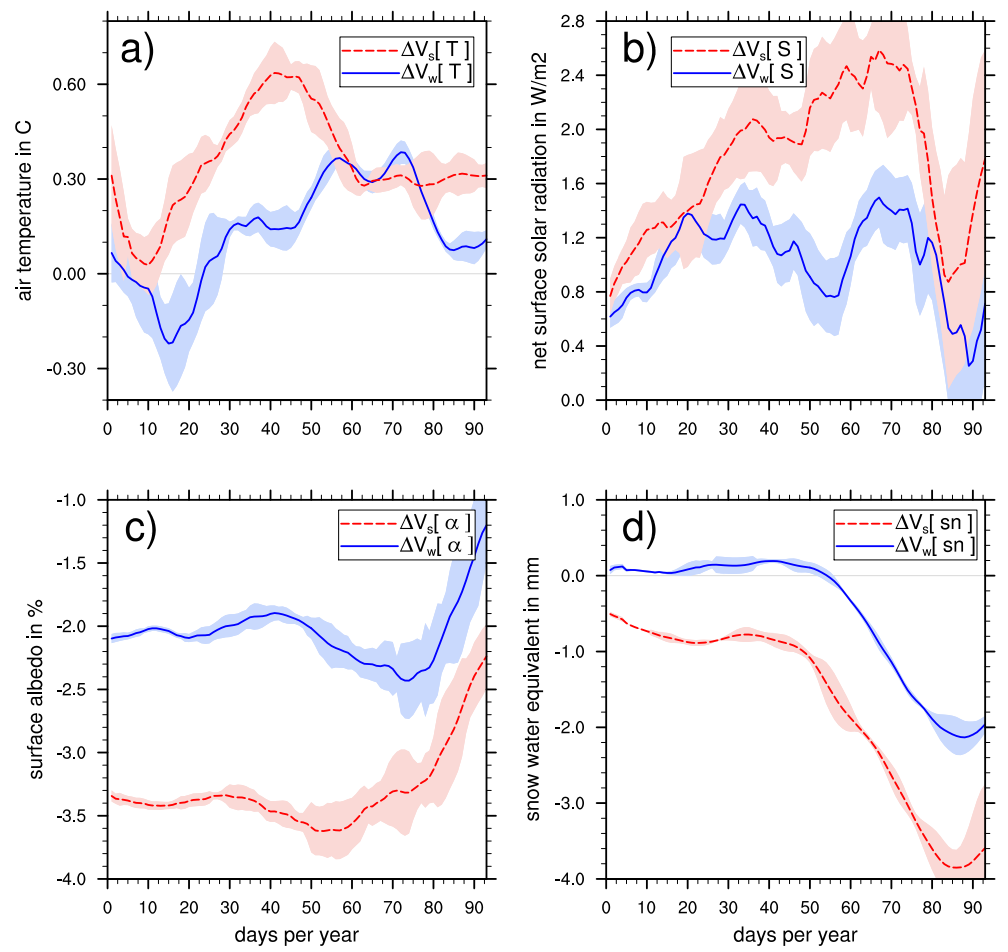

Fig. 4. Spring cycle of the simulations with weak snow masking $\left(V_{\mathrm{W}}=\right.$ blue line $)$ and strong snow masking $\left(V_{\mathrm{S}}=\right.$ red, dashed line $)$ averaged over the land area north of $60^{\circ} \mathrm{N}$ for the following climate variables: (a) air-temperature in ${ }^{\circ} \mathrm{C}$, (b) net surface solar radiation in $\mathrm{W} \mathrm{m}^{-2}$, (c) surface albedo, and (d) snow water equivalent in $\mathrm{mm}$. The shaded areas indicate one standard deviation around the mean over 240 years. The time series are adjusted to the astronomical dates and smoothed by a 10-day running mean.
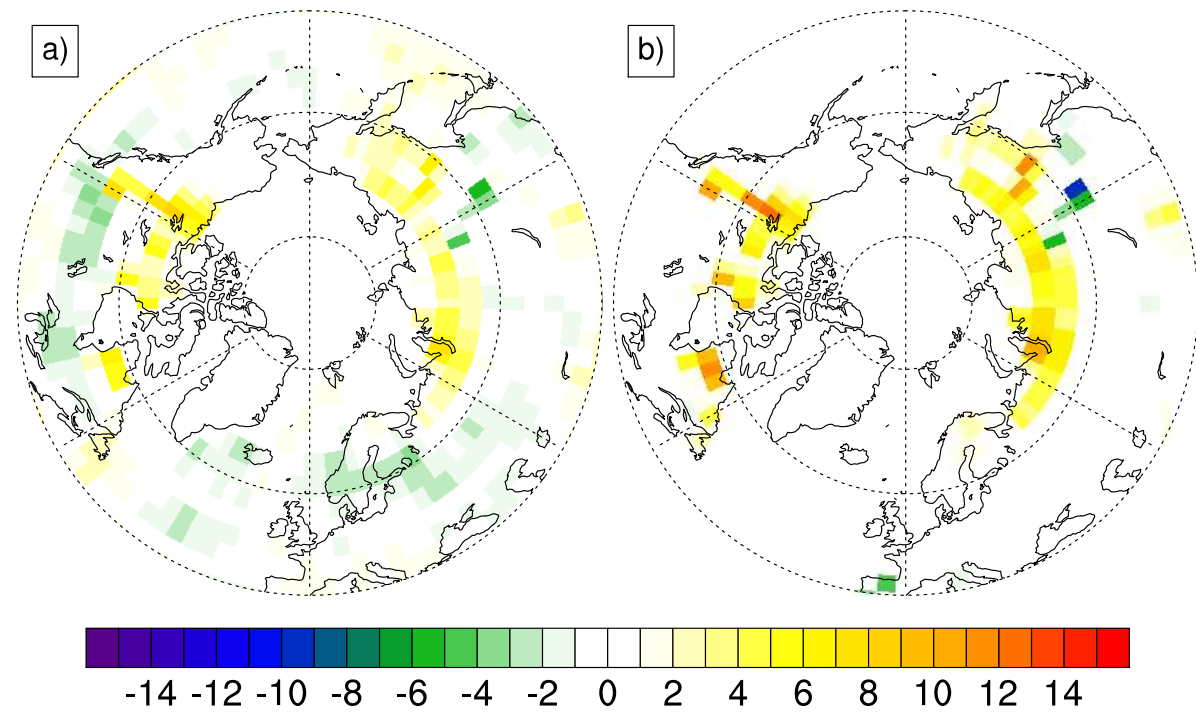

Fig. 5. Spring net surface radiation: (a) calculated spring net surface radiation $\delta S_{\text {est }}$ derived from the solar downward radiation for $0 \mathrm{k}$, the change in forest fraction from $0 \mathrm{k}$ to $6 \mathrm{k}$, and the strength of snow masking; (b) spring net surface radiation $\Delta V_{\mathrm{w}}[S]$.

et al., 2000). This is undermined not least by the fact that in our simulations, forest replaces mainly cold desert, i.e. areas without transpiration. This increase in transpiration possibly favours an increase in cloud fraction (Table 3 ) and thus counteracts the warming. In both experiments, the sensible and the latent fluxes increase (Table 3 ). We cannot derive from these set of simulations if this increase is caused by the expansion of forest, nor can we derive that the increase in 
total cloud fraction is the only process which weakens the net surface solar radiation.

\section{Comparison with previous studies}

To test how well the model can reproduce mid-Holocene climate derived from proxies, we compare our simulations with an available data set for summer, winter, and annual mean temperature over the northern high latitudes $60^{\circ} \mathrm{N}-90^{\circ} \mathrm{N}$ (Sundqvist et al., 2010a,b). As it is not possible to measure $\Delta V_{\mathrm{w}}$ and $\Delta V_{\mathrm{s}}$ directly in reality, we use the first term of the equation to calculate $\Delta V_{\mathrm{w}}$ and $\Delta V_{\mathrm{s}}$ which gives at least an indication on the validity of our results:

$$
\begin{aligned}
& \Delta \mathrm{AV}_{\mathrm{w}}=\left(6 \mathrm{k}(\mathrm{AV})_{\mathrm{w}}-0 \mathrm{k}(\mathrm{AV})_{\mathrm{w}}\right) \\
& \Delta \mathrm{AV}_{\mathrm{s}}=\left(6 \mathrm{k}(\mathrm{AV})_{\mathrm{s}}-0 \mathrm{k}(\mathrm{AV})_{\mathrm{s}}\right)
\end{aligned}
$$

Summer, winter and annual temperatures are derived from $\triangle A V_{\mathrm{w}}$ and $\Delta \mathrm{AV}_{\mathrm{s}}$, averaged for the land north of $60^{\circ} \mathrm{N}$ and are compared with reconstructions. With both sets of simulations, we simulate much lower temperatures in winter $\left(\Delta(\mathrm{AV})_{\mathrm{W}}=-0.04^{\circ} \mathrm{C}, \Delta(\mathrm{AV})_{\mathrm{s}}=0.01^{\circ} \mathrm{C}\right)$ and in the annual mean $\left(\Delta(\mathrm{AV})_{\mathrm{W}}=0.24^{\circ} \mathrm{C}, \Delta(\mathrm{AV})_{\mathrm{s}}=0.35^{\circ} \mathrm{C}\right)$ compared to the reconstructions (winter: $\sim 1.70^{\circ} \mathrm{C}$, annual: $\sim 2.00^{\circ} \mathrm{C}$, respectively Sundqvist et al., 2010a,b). For summer, ECHAM5/JSBACH overestimates the mid-Holocene warming by almost $1{ }^{\circ} \mathrm{C}\left(\Delta(\mathrm{AV})_{\mathrm{W}}=1.82^{\circ} \mathrm{C}, \Delta(\mathrm{AV})_{\mathrm{s}}=1.97^{\circ} \mathrm{C}\right)$ compared to reconstructed summer temperature of only $\sim 1.00^{\circ} \mathrm{C}$ (Sundqvist et al., 2010a,b).

The mismatch between the model simulations and reconstructions has likely several reasons: (1) the simulations were performed without dynamic ocean and thus neglected important interactions between ocean, sea ice, land, and atmosphere (Otto et al., 2009a; Zhang et al., 2010). (2) The reconstructed temperature values are an unweighted average over the region north of $60^{\circ} \mathrm{N}$ (Sundqvist et al., 2010a). (3) The average of the reconstructed temperature depends on the uncertainty in individual reconstructions and the number of sites. For example, the sparsity of winter temperature reconstructions make the estimated change in winter less reliable than the reconstructed summer and annual mean temperatures (Sundqvist et al., 2010a).

Reconstructions of the mid-Holocene treeline suggest an asymmetric response of the vegetation to the change in insolation (MacDonald et al., 2000; Bigelow et al., 2003). The reconstructions show northward shifts of forest by up to $200 \mathrm{~km}$ in Central Siberia, and 50-100 km in Western Europe and in North-West Canada. For Eastern Canada, reconstruction suggests that the tree line was further south than present (Kerwin et al., 1999; Bigelow et al., 2003). The simulated northward extension in forest area for the mid-Holocene is in general agreement with the reconstructions (see Fig. 3). The increase in deciduous forest in Eastern Siberia is also supported by reconstructions (Texier et al., 1997). Wohlfahrt et al. (2008) presented an evaluation of GCM simulations of the mid-Holocene with palaeovegetation data. In their study, the different GCMs simulate an increase in forest between $6-16 \times 10^{5} \mathrm{~km}^{2}$ north of $60^{\circ} \mathrm{N}$. Our results with an increase in forest between $11.29-12.71 \times 10^{5} \mathrm{~km}^{2}$ are in the range of the results by Wohlfahrt et al. (2008).

The first study of vegetation-atmosphere interaction under mid-Holocene forcing was undertaken by Ganopolski et al. (1998). Their model CLIMBER-2 in its current version (Ganopolski, personal communication, 2011) yields an increase in forest area by $18.10 \times 10^{5} \mathrm{~km}^{2}$ and an increase in spring temperature of $0.30^{\circ} \mathrm{C}$ over land north of $60^{\circ} \mathrm{N}$ with a decrease in surface albedo of -0.05 . These values correspond to our results. We simulated a slightly weaker increase in forest area by $11.29 \times 10^{5} \mathrm{~km}^{2}\left(\Delta \mathrm{AV}_{\mathrm{w}}\right)$ and $12.71 \times 10^{5} \mathrm{~km}^{2}\left(\Delta \mathrm{AV}_{\mathrm{s}}\right)$ and a weaker reduction in surface albedo $\left(\Delta V_{\mathrm{w}}[\alpha]=-0.02, \Delta V_{\mathrm{s}}[\alpha]=-0.03\right)$. This leads to a weaker spring warming with the simulations of weak masking $\left(\Delta V_{\mathrm{w}}[T]=0.12^{\circ} \mathrm{C}\right)$, but the simulations with strong snow masking yield a similar strong spring warming $\left(\Delta V_{\mathrm{s}}[T]=0.34^{\circ} \mathrm{C}\right)$. In comparison, these values are smaller than the simulated vegetation contribution to spring warming in the simulations with MoBidiC by Crucifix et al. (2002) that showed a spring warming of $5^{\circ} \mathrm{C}$. On the other hand, the expansion of forest exceeds by a factor of about four our forest increase. Wohlfahrt et al. (2004) coupled the vegetation model BIOME1 asynchronously with the GCM IPSL. Their simulations, however, show a spring warming that reaches $0.95^{\circ} \mathrm{C}$ averaged over the region north $40^{\circ} \mathrm{N}$ with an expansion of forest which amounts to only half of our simulated increase in forest.

The spread in simulated spring warming by the vegetation may be related to several causes. One reason may be the use of different models and parameterisations. Qu and Hall (2007) showed a large intermodel spread in the strength of the surface-albedo feedback which is attributable to the type of surface-albedo parameterisation. Models with simpler snow albedo parameterisation tend to show higher albedo values under snow conditions than more complex models that explicitly take into account the influence of vegetation on the albedo. We were able to show that the spring warming exhibits a threefold increase when the snow albedo is reduced more strongly by the vegetation canopy, compared to a less pronounced reduction.

\section{Conclusions}

We show that the simulated magnitude of spring warming depends on the parameterisation of the albedo of snow. With a doubling of the strength of snow masking, spring warming is increased by a factor three. This temperature increase goes along with an additional gain of total forest of only $13 \%$.

The expansion of forest and its snow masking are likely the main land components that drive vegetation-climate 
interactions and lead to a spring warming. This is an assumption which could be re-assessed by a more detailed factor analysis in which the contribution of other processes like transpiration and evaporation from the land surface are considered. Such processes could affect cloudiness and the wet greenhouse effect. For example, an increase in water vapour due to enhanced transpiration would tend to amplify the snow-masking effect via a stronger wet greenhouse effect, while an increase in cloudiness would tend to counteract the snow-masking effect. It is likely that hydrological processes are more important processes relative to the snowmasking in summer than in spring (e.g. Claussen, 2004).

Hence, the main conclusion of our study is that even if the snow-masking effect is strongly enhanced, the pure contribution of vegetation-atmosphere interaction to the difference between mid-Holocene and present-day's spring warming remains weak. In this respect our study is in line with the suggestion by Braconnot et al. (2007) that the magnitude of vegetation-climate interaction could be smaller than previously suggested (e.g. Crucifix et al., 2002; Wohlfahrt et al., 2004).

\section{Appendix A}

\section{Maps of leaf albedo and soil albedo}

For each PFT a specific albedo of the canopy (green leaves) $\alpha_{\text {leaf }}$ is given for visible (VIS) and near-infrared (NIR) range (Table A1). These values are derived from two maps of $\alpha_{\text {leaf }}$ for each of the spectral bands. The soil albedo, $\alpha_{\text {soil }}$, is read in as two maps (VIS and NIR) at the beginning of each experiment. The four maps of $\alpha_{\text {leaf }}$ and $\alpha_{\text {soil }}$ have been calulated from the sensor Moderate-Resolution Imaging Spectroradiometer (MODIS) (Schaaf et al., 2002) reflectance data in a manner similar to Rechid et al. (2008).

The maps of $\alpha_{\text {leaf }}$ and $\alpha_{\text {soil }}$ are derived by linear regression of the fraction of absorbed photosynthetically active radiation fapar $(t)$ on total surface albedo $\alpha(t)$. Both data sets, fapar $(t)$ and $\alpha(t)$, are based on measurements taken by MODIS aboard the TERRA satellite in the years 2001-2004. Here we use the white sky albedo of VIS and NIR range included in the product MOD43C1, which specifies the albedo on a $0.05^{\circ}$ grid in 16 day periods. White sky albedo (also referred to as bi-hemispherical reflectance) is the reflectance of a surface under diffuse illumination (same radiance for all viewing directions). It is considered to be a good proxy of the daily average albedo, which is the decisive parameter in the context of climate modelling. Only at high latitudes does it slightly underestimate albedo, as the solar zenith angle is large throughout the whole day.

The fapar data are taken from the product MOD15A2, which provides 8 day fapar composites on a $1 \mathrm{~km}$ sinussoidal grid. Both (albedo and fapar) data sets are remapped to a $0.25^{\circ}$ grid excluding pixels with snow cover and the fapar
Table A1. $\alpha_{\text {leaf }}$ values for VIS and NIR for each PFT derived from MODIS data set.

\begin{tabular}{lcc}
\hline PFT & Albedo VIS & Albedo NIR \\
\hline Forest tropical evergreen & 0.03 & 0.21 \\
Forest tropical deciduous & 0.04 & 0.23 \\
Forest temperate/boreal evergreen broadleaf & 0.05 & 0.25 \\
Forest temperate/boreal deciduous broadleaf & 0.07 & 0.28 \\
Forest temperate/boreal evergreen needleleaf & 0.05 & 0.26 \\
Forest temperate/boreal deciduous needleleaf & 0.05 & 0.26 \\
Shrubs raingreen & 0.05 & 0.25 \\
Shrubs cold & 0.07 & 0.28 \\
Grass C3 & 0.08 & 0.34 \\
Grass C4 & 0.08 & 0.34 \\
\hline
\end{tabular}

fields are averaged over the 16 day periods of the albedo data set.

The linear regression is done separately for the visible range (incl. UV radiation, $0.3-0.7 \mu \mathrm{m}$ ) and the NIR range $(0.7-3 \mu \mathrm{m})$ in the following way:

$\alpha(t)=\operatorname{fcover}(t) \alpha_{\text {leaf }}+(1-$ fcover $(t)) \alpha_{\text {soil }}$

Here fcover $(t)$ is the fraction of the grid box covered by a green canopy. For the visible range it can be approximately assumed that $f \operatorname{cover}(t)=f a p a r(t) /\left(1-\alpha_{\text {leaf }}\right)$. This implies that the difference in the reflectivity of UV radiation and the photosynthetically active radiation (i.e. the visible radiation) has no substantial influence on the total reflectivity as well as that the radiation reflected at the soil beneath the canopy and penetrating the canopy thereafter is negligible.

$\alpha_{\text {vis }}(t)=\frac{\operatorname{fapar}(t)}{1-\alpha_{\text {leaf, vis }}} \alpha_{\text {leaf,vis }}+\left(1-\frac{\operatorname{fapar}(t)}{1-\alpha_{\text {leaf,vis }}}\right) \alpha_{\text {soil,vis }}$

The coefficients $a$ and $b$ of the linear relation $\alpha_{\text {vis }}$ (fapar) $=a \times$ fapar $+b$ are specified by the linear regression of fapar on $\alpha_{\text {vis }}$, so that $\alpha_{\text {leaf,vis }}$ and $\alpha_{\text {soil, vis }}$ can be calculated:

$$
\begin{aligned}
& \alpha_{\text {vis }}(\text { fapar }=0)=b=\alpha_{\text {soil,vis }} \\
& \begin{aligned}
\alpha_{\text {vis }}(\text { fapar }=1) & =a+b \\
& =\frac{1}{1-\alpha_{\text {leaf, vis }}} \alpha_{\text {leaf,vis }}+\left(1-\frac{1}{1-\alpha_{\text {leaf,vis }}}\right) \alpha_{\text {soil, vis }} \\
\Longrightarrow \alpha_{\text {leaf, vis }} & =\frac{a+b}{1+a}
\end{aligned}
\end{aligned}
$$

After $\alpha_{\text {leaf,vis }}$ and $\alpha_{\text {soil, vis }}$ have been determined by linear regression, also $\alpha_{\text {leaf,nir }}$ and $\alpha_{\text {soil, nir }}$ are calculated similarly according to the equation:

$$
\alpha_{\text {nir }}(t)=\frac{\operatorname{fapar}(t)}{1-\alpha_{\text {leaf, vis }}} \alpha_{\text {leaf,nir }}+\left(1-\frac{\operatorname{fapar}(t)}{1-\alpha_{\text {leaf, vis }}}\right) \alpha_{\text {soil,nir }}
$$

The albedo values $\alpha_{\text {soil,vis }}, \alpha_{\text {leaf,vis }}, \alpha_{\text {soil,nir, and } \alpha_{\text {leaf,nir }}}$ are used for the calculation of the albedo in JSBACH (see Appendix B). 


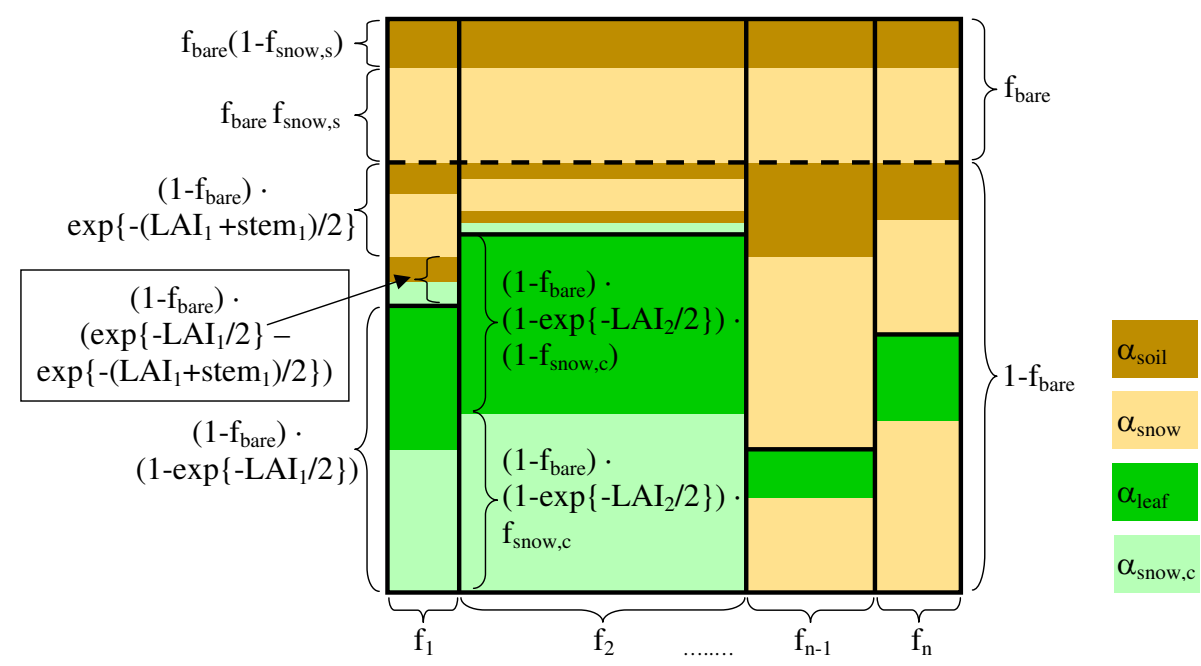

Fig. B1. Illustration of the terms in the Eqs. (B1) and (B2). In this example tile 1 and tile 2 are covered by forest, whereas tile $n-1$ and tile $n$ are occupied by grasses or shrubs.

\section{Appendix B}

\section{Albedo calculation in JSBACH}

The surface albedo of each gridbox in JSBACH is calculated in several steps. Each land gridbox is subdivided into tiles that represent different PFTs. The current version of JSBACH includes eight different PFTs. For these tiles the albedo, $\alpha_{i}$, is calculated. The albedo values of all tiles are then weighted by their fractional cover, $f_{i}$, and summed to a gridbox average albedo. This is done separately for VIS (wavelength $0.3-0.7 \mu \mathrm{m})$ and NIR $(0.7-3.0 \mu \mathrm{m})$. Finally, the albedo values are passed to the atmospheric model ECHAM5 to be used in the radiation routine.

The albedo of each tile, $\alpha_{i}$, is calculated from the albedo of the canopy (green leaves), $\alpha_{\text {leaf }}$ (Appendix A), the albedo of soil, $\alpha_{\text {soil }}$ (Appendix A), the albedo of snow covered soil $\alpha_{\text {snow }}$, and the albedo of snow covered forest canopies $\alpha_{\text {snow,c. }}$ The albedo of each tile is calculated for VIS and NIR but to simplify the equations we omit the subscript vis and nir.

The albedo of snow, $\alpha_{\text {snow }}$, is temperature-dependent. It decreases linearly with surface temperature, ranging from a minimum value at the melting point $\left(\alpha_{\mathrm{snow}, \text { vis }}=0.5\right.$, $\alpha_{\text {snow, nir }}=0.3$, in the simulation with strong snow masking set to $\alpha_{\text {snow,nir }}=0.4$ ) to a maximum value for temperatures of less than $-5^{\circ} \mathrm{C}\left(\alpha_{\text {snow, vis }}=0.9, \alpha_{\text {snow,nir }}=0.7\right)$. The albedo of snow-covered canopy is set to either $\alpha_{\text {snow,c }}=0.25$ or for the set of simulations with strong snowmasking to $\alpha_{\text {snow }, \mathrm{c}}=0.20$.

If the vegetation type is grass or shrub, snow on the soil is assumed to also cover the leaves. The albedo of a tile, $\alpha_{i}$, which is covered by either grass or shrubs is aggregated as follows. The snow covered fraction of the soil is $f_{\text {snow,s }}$, and the fraction of each gridbox, which is free of any vegetation is $f_{\text {bare }}$.

$$
\begin{aligned}
\alpha_{i} & =\left(f_{\text {bare }}+\left(1-f_{\text {bare }}\right) e^{-\mathrm{LAI}_{i} / 2}\right)\left(1-f_{\text {snow }, \mathrm{s}}\right) \alpha_{\text {soil }} \\
& +\left(1-f_{\text {bare }}\right)\left(1-e^{-\mathrm{LAI}_{i} / 2}\right)\left(1-f_{\text {snow }, \mathrm{s}}\right) \alpha_{\text {leaf }} \\
& +f_{\text {snow }, \mathrm{s}} \alpha_{\text {snow }}
\end{aligned}
$$

The first line of Eq. (B1) represents the albedo of the area which is neither covered by leaves nor by snow, the second line the albedo of the area covered by green leaves, and the third line the albedo of snow-covered soil. Whereas for forests, the snow on the canopy as well as the masking of snow on the soil by the canopy are considered:

$$
\begin{aligned}
\alpha_{i} & =\left(f_{\text {bare }}+\left(1-f_{\text {bare }}\right) e^{-(\mathrm{LAI} i+\text { stem }) / 2}\right) \\
& \left(\left(1-f_{\text {snow }, \mathrm{s}}\right) \alpha_{\text {soil }}+f_{\text {snow }, s} \alpha_{\text {snow }}\right) \\
& +\left(1-f_{\text {bare }}\right)\left(e^{-\mathrm{LAI}_{i} / 2}-e^{-(\mathrm{LAI} i+\text { stem }) / 2}\right)\left(\left(1-f_{\text {snow }, \mathrm{c})}\right) \alpha_{\text {soil }}+f_{\text {snow }, \mathrm{c}} \alpha_{\text {snow }, \mathrm{c}}\right) \\
& +\left(1-f_{\text {bare }}\right)\left(1-e^{-\mathrm{LAI}_{i} / 2}\right)\left(\left(1-f_{\text {snow }, \mathrm{c}}\right) \alpha_{\text {leaf }}+f_{\text {snow }, c} \alpha_{\text {snow }, \mathrm{c}}\right)
\end{aligned}
$$

The first two lines of Eq. (B2) represent the albedo of the area which is not covered by vegetation (green leaves), the third line gives the albedo of the area covered by stems and branches (stem), and the fourth line the albedo of area which is covered by green leaves. A stem area index of 1 for all forest types is introduced, in particular to account for the snow masking of deciduous forest. In the set of simulations with strong snow masking, the stem area index is set to 3 .

A summary of how the albedo of the different surfaces is aggregated is illustrated in Fig. B1. 
Acknowledgements. The authors thank Andrey Ganopolski, Potsdam Institute for Climate Impact Research, and three anonymous reviewers for the constructive comments and discussion. Part of the work was undertaken while Juliane Otto was funded by the International Max Planck Research School on Earth System Modelling in Hamburg. Currently Juliane Otto is employed on ERC starting grant 242564.

The service charges for this open access publication have been covered by the Max Planck Society.

Edited by: V. Rath

\section{References}

Barlage, M., Zeng, X. B., Wei, H. L., and Mitchell, K. E.: A global 0.05 degrees maximum albedo dataset of snow-covered land based on MODIS observations, Geophys. Res. Lett., 32, L17405, doi:10.1029/2005GL022881, 2005.

Berger, A.: Long-Term Variations Of Daily Insolation And Quaternary Climatic Changes, J. Atmos. Sci., 35, 2362-2367, 1978.

Berger, A., Claussen, M., and Yin, Q.: Factor separation method and palaeoclimates, in: Factor Separation in the AtmosphereApplications and Future Prospects, edited by: Alpert, P. and Sholokhman, T., Cambridge Univ. Press, 2011.

Beringer, J., Chapin, F. S., Thompson, C. C., and McGuire, A. D.: Surface energy exchanges along a tundra-forest transition and feedbacks to climate, Agr. Forest Meteorol., 131, 143-161, 2005.

Betts, A. K. and Ball, J. H.: Albedo over the boreal forest, J. Geophys. Res., 102, 28901-28909, 1997.

Bigelow, N. H., Brubaker, L. B., Edwards, M. E., Harrison, S. P., Prentice, I. C., Anderson, P. M., Andreev, A. A., Bartlein, P. J., Christensen, T. R., Cramer, W., Kaplan, J. O., Lozhkin, A. V., Matveyeva, N. V., Murray, D. F., McGuire, A. D., Razzhivin, V. Y., Ritchie, J. C., Smith, B., Walker, D. A., Gajewski, K., Wolf, V., Holmqvist, B. H., Igarashi, Y., Kremenetskii, K., Paus, A., Pisaric, M. F. J., and Volkova, V. S.: Climate change and Arctic ecosystems: 1 . Vegetation changes north of 55 degrees $\mathrm{N}$ between the last glacial maximum, mid-Holocene, and present, J. Geophys. Res., 108, 8170, 2003.

Braconnot, P., Otto-Bliesner, B., Harrison, S., Joussaume, S., Peterchmitt, J.-Y., Abe-Ouchi, A., Crucifix, M., Driesschaert, E., Fichefet, Th., Hewitt, C. D., Kageyama, M., Kitoh, A., Loutre, M.-F., Marti, O., Merkel, U., Ramstein, G., Valdes, P., Weber, L., Yu, Y., and Zhao, Y.: Results of PMIP2 coupled simulations of the Mid-Holocene and Last Glacial Maximum Part 2: feedbacks with emphasis on the location of the ITCZ and mid- and high latitudes heat budget, Clim. Past, 3, 279-296, doi:10.5194/cp-3-279-2007, 2007.

Brovkin, V., Raddatz, T., Reick, C. H., Claussen, M., and Gayler, V.: Global biogeophysical interactions between forest and climate, Geophys. Res. Lett., 36, L07405, doi:10.1029/2009GL037543, 2009.

Chapin, F. S., McGuire, A. D., Randerson, J., Pielke, R., Baldocchi, D., Hobbie, S. E., Roulet, N., Eugster, W., Kasischke, E., Rastetter, E. B., Zimov, S. A., and Running, S. W.: Arctic and boreal ecosystems of western North America as components of the climate system, Global Change Biol., 6, 211-223, 2000.
Claussen, M.: The Global Climate - Chapter A.4, in: Vegetation, Water, Humans and the Climate: A New Perspective on an Interactive System, edited by: Kabat, P., Claussen, M., Dirmeyer, P. A., Gash, J. H. C., Guenni, L., Meybeck, M., Pielke, R. A., Vörösmarty, C. J., and Lütkemeier, S., Springer-Verlag, Heidelberg, 2004.

Crucifix, M., Loutre, M. F., Tulkens, P., Fichefet, T., and Berger, A.: Climate evolution during the Holocene: a study with an Earth system model of intermediate complexity, Clim. Dynam., 19, 43-60, 2002.

Dery, S. J. and Brown, R. D.: Recent Northern Hemisphere snow cover extent trends and implications for the snow-albedo feedback, Geophys. Res. Lett., 34, L22504, doi:10.1029/2007GL031474, 2007.

Essery, R., Rutter, N., Pomeroy, J., Baxter, R., Stahli, M., Gustafsson, D., Barr, A., Bartlett, P., and Elder, K.: An Evaluation of Forest Snow Process Simulations, B. Am. Meteorol. Soc., 90, 1120-1135, 2009.

Eugster, W., Rouse, W. R., Pielke, R. A., McFadden, J. P., Baldocchi, D. D., Kittel, T. G. F., Chapin, F. S., Liston, G. E., Vidale, P. L., Vaganov, E., and Chambers, S.: Land-atmosphere energy exchange in Arctic tundra and boreal forest: available data and feedbacks to climate, Global Change Biol., 6, 84-115, 2000.

Ganopolski, A., Kubatzki, C., Claussen, M., Brovkin, V., and Petoukhov, V.: The influence of vegetation-atmosphere-ocean interaction on climate during the mid-Holocene, Science, 280, 1916-1919, 1998.

Hall, A. and Qu, X.: Using the current seasonal cycle to constrain snow albedo feedback in future climate change, Geophys. Res. Lett., 33, L03502, doi:10.1029/2005GL025127, 2006.

Hall, A., Qu, X., and Neelin, J. D.: Improving predictions of summer climate change in the United States, Geophys. Res. Lett., 35, L01702, doi:10.1029/2007GL032012, 2008.

Harvey, L. D. D.: On The Role Of High-Latitude Ice, Snow, And Vegetation Feedbacks In The Climatic Response To External Forcing Changes, Climatic Change, 13, 191-224, 1988.

Jin, Y. F., Schaaf, C. B., Gao, F., Li, X. W., Strahler, A. H., and Zeng, X. B.: How does snow impact the albedo of vegetated land surfaces as analyzed with MODIS data?, Geophys. Res. Lett., 29, 1374, 2002.

Joussaume, S. and Braconnot, P.: Sensitivity of paleoclimate simulation results to season definitions, J. Geophys. Res., 102, 19431956, 1997.

Kerwin, M. W., Overpeck, J. T., Webb, R. S., DeVernal, A., Rind, D. H., and Healy, R. J.: The role of oceanic forcing in midHolocene Northern Hemisphere climatic change, Paleoceanography, 14, 200-210, 1999.

MacDonald, G. M., Velichko, A. A., Kremenetski, C. V., Borisova, O. K., Goleva, A. A., Andreev, A. A., Cwynar, L. C., Riding, R. T., Forman, S. L., Edwards, T. W. D., Aravena, R., Hammarlund, D., Szeicz, J. M., and Gattaulin, V. N.: Holocene treeline history and climate change across northern Eurasia, Quaternary Res., 53, 302-311, 2000.

Meehl, G., Stocker, T. W. D. C., Friedlingstein, F., Gaye, A., Gregory, J., Kitoh, A., Knutti, R., Murphy, J., Noda, A., Raper, S., Watterson, I., Weaver, A., and Zhao, Z.-C.: Global Climate Projections, in: Climate Change 2007: The Physical Science Basis, Contribution of Working Group I to the Fourth Assessment Report of the Intergovernmental Panel on Climate Change, edited 
by: Solomon, S., Qin, D., Manning, M., Chen, Z., Marquis, M., Averyt, K. B., Tignor, M., and Miller, H. L., 2007.

Moody, E. G., King, M. D., Schaaf, C. B., Hall, D. K., and Platnick, S.: Northern Hemisphere five-year average (2000-2004) spectral albedos of surfaces in the presence of snow: Statistics computed from Terra MODIS land products, Remote Sens. Environ., 111, 337-345, 2007.

Otterman, J., Chou, M. D., and Arking, A.: Effects Of Nontropical Forest Cover On Climate, J. Clim. Appl. Meteorol., 23, 762-767, 1984.

Otto, J., Raddatz, T., and Claussen, M.: Climate variability-induced uncertainty in mid-Holocene atmosphere-ocean-vegetation feedbacks, Geophysical Research Letters, 36, L23 710, 2009a.

Otto, J., Raddatz, T., Claussen, M., Brovkin, V., and Gayler, V.: Separation of atmosphere-ocean-vegetation feedbacks and synergies for mid-Holocene climate, Geophys. Res. Lett., 36, L09701, doi:10.1029/2009GL037482, 2009b.

Pielke, R. A. and Vidale, P. L.: The boreal forest and the polar front, J. Geophys. Res.-Atmos., 100, 25755-25758, 1995.

$\mathrm{Qu}, \mathrm{X}$. and Hall, A.: What controls the strength of snow-albedo feedback?, J. Climate, 20, 3971-3981, 2007.

Raddatz, T. J., Reick, C. H., Knorr, W., Kattge, J., Roeckner, E., Schnur, R., Schnitzler, K. G., Wetzel, P., and Jungclaus, J.: Will the tropical land biosphere dominate the climate-carbon cycle feedback during the twenty-first century?, Clim. Dynam., 29, 565-574, 2007.

Rechid, D., Raddatz, T., and Jacob, D.: Parameterization of snowfree land surface albedo as a function of vegetation phenology based on MODIS data and applied in climate modelling, Theor. Appl. Climatol., 95, 245-255, 2008.

Roeckner, E., Bäuml, G., Bonaventura, L., Brokopf, R., Esch, M. M. G., Hagemann, S., Kirchner, I., Kornblueh, L., Manzini, E., Rhodin, A., Schlese, U., Schulzweida, U., and Tompkins, A.: The atmospheric general circulation model ECHAM5, Part I: Model description., Tech. Rep. Rep. 349, Max Planck Institute for Meteorology, Available from MPI for Meteorology, Hamburg, Germany, 127 pp., 2003.

Roesch, A. and Roeckner, E.: Assessment of snow cover and surface albedo in the ECHAM5 general circulation model, J. Climate, 19, 3828-3843, 2006.

Schaaf, C. B., Gao, F., Strahler, A. H., Lucht, W., Li, X. W., Tsang, T., Strugnell, N. C., Zhang, X. Y., Jin, Y. F., Muller, J. P., Lewis, P., Barnsley, M., Hobson, P., Disney, M., Roberts, G., Dunderdale, M., Doll, C., d'Entremont, R. P., Hu, B. X., Liang, S. L., Privette, J. L., and Roy, D.: First operational BRDF, albedo nadir reflectance products from MODIS, Remote Sens. Environ., 83, $135-148,2002$.
Schwartz, M. D. and Karl, T. R.: Spring Phenology - Natures Experiment To Detect The Effect Of Green-Up On Surface Maximum Temperatures, Mon. Weather Rev., 118, 883-890, 1990.

Stein, U. and Alpert, P.: Factor Separation In Numerical Simulations, J. Atmos. Sci., 50, 2107-2115, 1993.

Sturm, M., Douglas, T., Racine, C., and Liston, G. E.: Changing snow and shrub conditions affect albedo with global implications, J. Geophys. Res.-Biogeo., 110, G01004, doi:10.1029/2005JG000013, 2005.

Sundqvist, H. S., Zhang, Q., Moberg, A., Holmgren, K., Körnich, H., Nilsson, J., and Brattström, G.: Climate change between the mid and late Holocene in northern high latitudes - Part 1: Survey of temperature and precipitation proxy data, Clim. Past, 6, 591608, doi:10.5194/cp-6-591-2010, 2010a.

Sundqvist, H. S., Zhang, Q., Moberg, A., Holmgren, K., Körnich, H., Nilsson, J., and Brattström, G.: Corrigendum to "Climate change between the mid and late Holocene in northern high latitudes - Part 1: Survey of temperature and precipitation proxy data" published in Clim. Past, 6, 591-608, 2010, Clim. Past, 6, 739-743, doi:10.5194/cp-6-739-2010, 2010b.

Texier, D., de Noblet, N., Harrison, S. P., Haxeltine, A., Jolly, D., Joussaume, S., Laarif, F., Prentice, I. C., and Tarasov, P.: Quantifying the role of biosphere-atmosphere feedbacks in climate change: coupled model simulations for 6000 years BP and comparison with palaeodata for northern Eurasia and northern Africa, Clim. Dynam., 13, 865-882, 1997.

Timm, O., Timmermann, A., Abe-Ouchi, A., Saito, F., and Segawa, T.: On the definition of seasons in paleoclimate simulations with orbital forcing, Paleoceanography, 23, PA2221, doi:10.1029/2007PA001461, 2008.

Wohlfahrt, J., Harrison, S. P., and Braconnot, P.: Synergistic feedbacks between ocean and vegetation on mid- and high-latitude climates during the mid-Holocene, Clim. Dynam., 22, 223-238, 2004.

Wohlfahrt, J., Harrison, S. P., Braconnot, P., Hewitt, C. D., Kitoh, A., Mikolajewicz, U., Otto-Bliesner, B. L., and Weber, S. L.: Evaluation of coupled ocean-atmosphere simulations of the mid-Holocene using palaeovegetation data from the Northern Hemisphere extratropics, Clim. Dynam., 31, 871-890, doi:10.1007/s00382-008-0415-5, 2008.

Zhang, Q., Sundqvist, H. S., Moberg, A., Körnich, H., Nilsson, J., and Holmgren, K.: Climate change between the mid and late Holocene in northern high latitudes - Part 2: Model-data comparisons, Clim. Past, 6, 609-626, doi:10.5194/cp-6-609-2010, 2010. 